\title{
The Age-Related Trend in Blood Pressure and the Prevalence of Hypertension in Korean Adults
}

\author{
Dae-Taek Lee* and Yong-Soo Lee
}

Kim Chang Kew Exercise Physiology Laboratory, Kookmin University, Seoul 136-702, Korea

Received May 10, 2011 /Revised February 3, 2012 /Accepted February 6, 2012

\begin{abstract}
A cross-sectional analysis of blood pressure (BP) changes and the current prevalence and distribution of hypertension among age groups in Korea were conducted. Systolic (SBP), diastolic (DBP), and pulse (PP) pressures were evaluated. Residents visiting a local Community Health Center for a health check-up and/or participating in the Health Promotion Program were included for the analyses. A total of 6,570 subjects $(2,809$ men, 3,761 women) were divided into five age groups: 30-39, 40-49, 50-59, $60-69$, and $70 \leq$ years. Comparisons were made between sex and among age groups. SBP and DBP were continuously elevated, while men showed higher levels than women until their mid-60s; then, the trend was reversed. DBP in men became elevated from their 30s, reaching the highest in the 40s then slowly decreasing. DBP in women increased up to their 40 s and 50 s, then reached a plateau. PP increased rapidly from the 50s in both sexes. The major contributor of age-related BP elevation may be large artery stiffness in men, particularly from their 50s, while the blood pressure elevation of women may relate to diverse factors including large artery stiffness, stroke volume, and ventricular ejection rate. The rapid elevation of PP after the 50s in both men and women could represent a risk of cardiovascular or coronary mortality, particularly with increasing age. The current data showed a higher rate of hypertension in both sexes compared to previous reports. When those with both high-normal BP and hypertension are looked at in combination, BP management of the target population should be drastically elevated.
\end{abstract}

Key words : Systole, diastole, pulse pressure, sex difference, age groups

\section{서 론}

고혈압은 의학적으로나 공중보건의 입장에서 주요관심 대 상이다. 고혈압이 사망률, 뇌졸중, 관상심장질환, 심부전, 말초 혈관질환, 신부전과 같은 많은 질환들과 밀접한 연관성이 존 재하는 것으로 알려지고 있기 때문이다[1,27]. 고혈압의 심혈 관질환과의 연관성은 성별, 연령, 인종을 불문하고 지속적이 고 강력하게 나타나며 혈압의 증가와 동반되어 심혈관질환의 위험성은 가중된다[13,25]. 수축기혈압(systolic blood pressure: $\mathrm{SBP}) 20 \mathrm{mmHg}$ 또는 이완기혈압(diastolic blood pressure: $\mathrm{DBP}$ )이 $10 \mathrm{mmHg}$ 증가할 때마다 허혈성 심장질환과 뇌졸중으로 인한 사망률이 두 배 증가한다고 보고된다[7]. 청 년기 이후 나이가 들면서 혈압은 점차로 증가하는데 60대에 이르면 인구의 약 과반수가 고혈압을 갖게 되고 70세 이후에 는 4명중 1 명이 그 영향을 받게 된다[5]. 프레이밍햄심장연구 에 의하면 55-65세까지 정상적인 혈압을 유지하고 있는 사람 일지라도 이들이 80-85세까지 생존하는 경우 고혈압이 발달할 위험성은 $90 \%$ 에 이르는 것으로 알려지고 있다[27].

고혈압의 발생과 진행 양태는 연령과 성별에 따라 다르게

*Corresponding author

Tel : +82-2-910-4781, Fax : +82-2-910-4789

E-mail : dtlee@kookmin.ac.kr
나타난다. 청년기와 중장년기까지는 남성이 여성에 비해 높은 수치를 보이지만, 노년기에 접어들면서 여성이 남성에 비해 더 많이 발병하여 여성에게서 더 높은 유병률을 보인다. 연령에 따라 $\mathrm{SBP}$ 와 $\mathrm{DBP}$ 가 변화하는 양상도 다르다. $\mathrm{SBP}$ 는 생애주기 전반에서 증가하지만, $\mathrm{DBP}$ 는 약 60 세까지 완만한 증가 추세를 보이다가 이후 점차 감소 또는 유지하는 경향을 보이게 된다[5].

많은 연구들은 고혈압의 병리적 현상을 이해하는 한편, 고 혈압 발전 현상에서 어떠한 변인이 심장질환과 사망률을 예측 할 수 있을지에 관해 관심을 가져왔다 $[8,13,14,26,27]$. 현재 고 혈압 진단과 관리를 위해 제안되고 있는 가이드라인은 DBP 증가를 동반하여 $\mathrm{SBP}$ 가 증가하는 경우는 물론 $\mathrm{DBP}$ 증가를 동반하지 않으면서도 $\mathrm{SBP}$ 만이 증가하는 경우도 포함시키고 있다[7]. 고혈압을 규정하는데 SBP를 중요하게 여기는 이유는 뇌졸중과 관상심장질환을 예견하는데 $\mathrm{DBP}$ 보다 더 정확성을 제공하기 때문이다[20]. 몇몇 연구들은 맥압(pulse pressure: $\mathrm{PP})$ 의 중요성을 강조하기도 한다[2,11,12,21,24].

혈압이 인체에 미치는 영향의 측면에서 보면 혈압은 원리적 으로 정적요인과 박동성 요인을 모두 가진다. 전자는 평균동 맥압(mean arterial pressure: MAP)을 일컬으며, 후자는 PP를 가리킨다. 다시 MAP는 심실박출(ventricular ejection)과 말초 혈 관저항(peripheral vascular resistance)이, 그리고 $\mathrm{PP}$ 는 직 접성 원인인 큰동맥의 점탄성질(viscoelastic properties)과 간 
접성 원인인 파장반사(wave reflection)로 결정지어진다[20]. 중년에서부터 노년까지의 주로 $\mathrm{SBP}$ 와 $\mathrm{PP}$ 가 증가하는 이유가 바로 이러한 기전에 의한다. 즉 $\mathrm{SBP}$ 의 증가는 우선적으로 큰 동맥들이 굳어지기 때문이며, 동시에 파장반사가 커지기 때문 이다[20]. 연령에 따라 증가하는 MAP와 PP의 변화는 30-50대 에서 거의 평형적으로 이동하지만 60 대 이후에서는 SBP가 증 가하고 $\mathrm{DBP}$ 가 감소하는 경향을 보여 결과적으로 60 세 이후에 서는 PP가 급격하게 증가한다[10]. 몇몇 연구들에 의하면 PP 는 심혈관질환 유병률과 사망률의 가능한 예측인자로 제안되 고 있으며 특히 노년의 인구에서 더욱 유용할 수 있다고 제안 되고 있다[2,11,12].

2010년에 발간된 국민건강통계에 의하면 우리나라 30세 이 상 성인의 고혈압 유병률은 남자가 $35.1 \%$ 여자가 $28.9 \%$ 로 전 체 $31.9 \%$ 였으며, 이는 이전의 조사에 비해 증가하는 추세로 나타났다[18]. 설명한 것과 같이 고혈압은 다른 생활습관병들 과 동반되어 발생하는 경우가 많으며, 다양한 질환들과 높은 상호관계를 유지한다. 많은 보고들이 연령에 따른 변화추이를 제공하고 있으며, 공중보건에서도 고혈압관리를 위한 교육을 실시하고 있다. 그러나 보고된 결과들은 설문지나 문진을 통 해 얻어진 자료를 이용하여 분석하였으며, 다양한 건강지표 변인들과 함께 혈압을 직접적으로 측정하여 연구한 경우는 상대적으로 적다. 특히 $\mathrm{SBP}$ 외에 $\mathrm{DBP}$ 와 $\mathrm{PP}$ 와 같이 생물학적 으로 순환계에 영향을 미칠 수 있는 변인들에 대한 분석이 이루어지지 않았다. 예를 들어 평균혈압은 심박출량과 총말초 저항에 의해 결정되는데, 보통의 경우 심박출량이 변화하지 않는 것을 가정하면 혈압은 궁극적으로 총말초저항에 의해 결정된다. 총말초저항은 혈관벽의 점탄성질에 근거하며 이를 반영하는 지표로 PP가 사용되기도 한다. 노화와 동반되는 혈 관성질의 변형이 혈압의 상승을 유발하는 것이다[15]. 그러나 이러한 변화가 성별에 따라 다른 양상을 보이는지에 대해서는 아직 그 자료가 미흡하다. 또한 인종에 따라 다른 양상의 발병 률과 변화추이를 보이고 있는 것을 감안하면[6,19], 우리나라 의 자료를 이용하여 이러한 변인들에 대한 분석이 필요할 것 으로 보인다. 따라서 이번 연구는 횡단적 분석을 통해 우리나 라 한 지역사회의 연령대별 혈압변화 현상과 유병률 그리고 이 변화과정에서 성별간의 차이가 존재하는지의 여부와 외국 사례와 어떠한 동일성 또는 차이를 보이는지 알아보기 위해 실시되었다.

\section{재료 및 방법}

\section{대상자}

서울 K구 보건소에서 2009년부터 2010년까지 진행된 건강 검진과 건강캠페인 그리고 대사증후군관리센터와 주민센터 에서 진행된 건강증진사업에 참여한 모든 사람들을 대상자로 선정하였다. 대상자들에 대한 사전 선별과정이나 기준은 적용
되지 않았다. 참여자들은 건강변인 측정에 앞서 문진표를 작 성하였으며, 참여한 프로그램에 따른 신체적 변인이 측정되었 다. 연구 기간 동안 보건소 사업과 활동에 참여한 총 사례건수 는 9,267명이었으며, 이 연구에서 다루고자 하는 신체적 변인 에 대해 본 연구에서 분석하고자 하는 정보가 제공된 분석 대상자는 6,570 명(남자 2,809명, 여자 3,761명)이었다.

\section{문진표 작성}

모든 대상자들은 검진에 참여하기 전 해당 보건소에서 진행 하는 다양한 건강증진프로그램에서 사용하는 문진표를 작성 하였다. 문진표는 인구통계적 정보, 자신의 병력, 현재 복용하 고 있는 약에 대해 질문하였다. 또한 건강행위와 연관된 문항 에서는 흡연 및 음주, 스트레스, 영양, 운동, 정신건강 등에 대해 질문하였다. 이번 연구에서는 신장, 체중, 혈압, 총콜레스 테롤, 고밀도지단백 콜레스테롤을 분석변인으로 선정하였다.

\section{건강지표 변인 측정}

대상자들의 신체적 특징과 건강지표 변인이 측정되었다. 문 진표를 작성한 후에 신장과 체중이 측정되었으며, 이를 이용 하여 신체질량지수 $\left(\mathrm{kg} / \mathrm{m}^{2}\right)$ 가 환산되었다. 그리고 간호사의 관리하에 안정시 혈압이 측정되었다. 혈압측정을 위해 자동혈 압계(Biospace TM-2655P, 한국)가 사용되었다. 사용된 자동혈 압계는 영국고혈압협회(British Hypertension Society)로부터 성인을 대상으로 이용될 수 있는 등급을 인정받았으며, 신뢰 도와 타당도가 검증되었다[17]. $\mathrm{SBP}$ 와 $\mathrm{DBP}$ 를 이용하여 $\mathrm{PP}$ (SBP-DBP)가 환산되었다. 대상자들은 검진 전날 저녁부터 최 소한 10 시간의 금식과정을 거쳤으며, 검진 당일 아침 공복상 태로 전완 정맥혈관으로부터 혈액이 채취되었다. 혈액샘플은 EDTA가 포함된 일회용 용기를 이용하여 혈장이 분리되었다. 분리된 혈장은 보건소 임상병리사가 자동화학분석기(Hitachi 7060 , 일본)를 이용하여 총콜레스테롤과 고밀도지단백 콜레스 테롤을 분석하였다.

\section{자료정리 및 통계분석}

전체 대상자를 남녀로 구분하였으며, 5 개의 연령단위 (30-39, 40-49, 50-59, 60-69, 70 $)$ 로 나누었다. 대상자들 중에 측정에 의해 $\mathrm{SBP} \geq 140 \mathrm{mmHg}$ 이거나 $\mathrm{DBP} \geq 90 \mathrm{mmHg}$ 이거 나, 또는 문진표를 통해 본인이 의사로부터 고혈압 판정을 받 거나 항고혈압 의약품을 복용하고 있는 대상자들은 고혈압질 환자로 분류하였다[6]. 또한 SBP가 130-139 mmHg이거나 $\mathrm{DBP}$ 가 85-89 mmHg일 경우 높은정상혈압(high-normal blood pressure)으로 간주되었다[8]. 고혈압환자에게서 $\mathrm{PP}>63$ $\mathrm{mmHg}$ 인 경우 심각한 심혈관계 문제가 발생할 수 있으며, 이 수준을 PP 위험기준으로 간주하였다[21].

IBM SPSS Statistics 19 통계 프로그램을 사용하여 측정변인 들은 평균과 표준편차로 나타내었으며, 각 측정변인의 연령별 
비교는 남녀를 따로 구분하여 one-way ANOVA를 사용하였 다. 통계적으로 유의성이 나타난 경우 사후검증으로 Scheffe 방법을 도입하였다. 각 연령단위에서의 남녀 비교는 독립 t-test를 사용하였다. 통계적 유의정도는 $p<0.05$ 로 설정하였다.

\section{결 과}

본 연구에서 분석된 대상자들의 연령별, 성별 신장과 체중 은 Table 1에서 나타내고 있다. 그리고 이들의 성별 연령대별 혈압반응은 Fig. 1에서 나타내고 있다. 각 연령별 비교에서 남 자와 여자의 $\mathrm{SBP}, \mathrm{DBP}$ 및 $\mathrm{PP}$ 는 모두 통계적으로 유의함을 보였다(ANOVA, $p \times 0.05)$. 남녀 SBP는 모두 연령 증가와 함께 증가 양상을 보였으며, 남자의 경우 50대에서 60 대 사이에 통 계적으로 유의한 증가가 나타났다. 여자의 경우 30대부터 70대 까지 지속적으로 증가하였으며, 모든 연령대에서 통계적인 유 의성이 나타났다. 연령대별 남녀의 비교에서는 30 대에서 60 대 까지 차이를 보였으나 $(p<0.05), 70$ 대에서는 차이를 보이지 않 았다 $(p=0.622) . \mathrm{DBP}$ 의 경우 남자는 40 대에서 증가하여 이후 점 차적으로 감소하였으며, 70 대까지 감소의 경향이 유지되었다. 여자는 50대까지 증가하였다가 이후 유지되는 형태를 보였다. 남녀 간의 차이도 $\mathrm{SBP}$ 와 마찬가지로 모든 연령대에서 통계적 유의함을 보였으나 70대 이후에서는 차이를 나타내지 않았다. $\mathrm{PP}$ 는 남자의 경우 40 대에서 감소한 후 50 대부터 다시 증가하기 시작하여 이후의 연령대에서 지속적으로 증가하였다. 여자의 경우에서는 30대부터 지속적으로 증가하는 양상을 보였다.

분석 대상자 중 고혈압군과 높은정상혈압군의 신체적 특성 과 혈압변인 수치 그리고 혈중지질 변인은 Table 2에 나타내고 있다. 대부분의 변인에서 연령 대별 차이가 존재하였다. 그러 나 고혈압군의 경우 남자 SBP에서 연령별 차이가 나타나지 않았다. 남자의 경우 고혈압군과 높은정상그룹 모두에서 연령 이 증가할수록 신체질량지수가 감소하는 반면, 여자는 두 군 에서 모두 연령대별 신체질량지수의 추이가 관찰되지 않았다. 두 군 모두에서 남자는 총콜레스테롤이 연령에 따라 낮게 나 타나는 반면 여자는 증가하는 추이를 보였다. 고밀도지단백질 콜레스테롤은 연령에 따른 변화추이가 일관되게 나타나지 않 았다.

고혈압군과 높은정상혈압군 그리고 $\mathrm{PP}$ 위험군의 분석 대상 자 대비 발생률은 Fig. 2에서 보여주고 있다. 남자 고혈압군

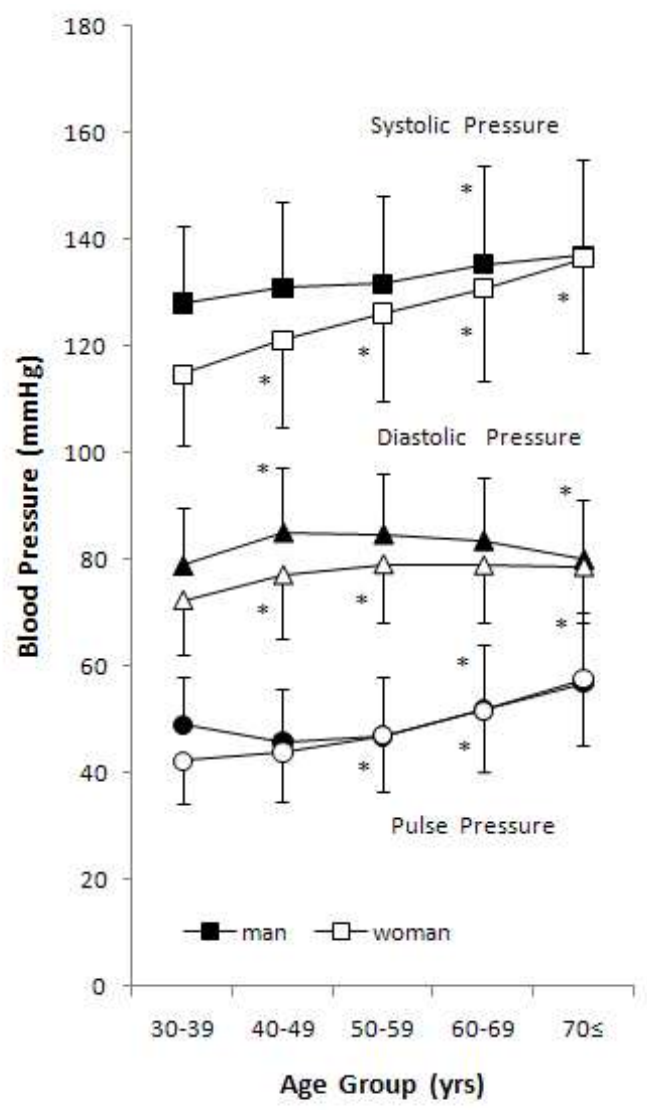

Fig. 1. Systolic, diastolic, and pulse pressures in man and woman by age group. Mean comparisons among age groups are statistically significant in both sex in all SBP, DBP, and PP (ANOVA, $p<0.05)$. *: significantly different with the previous age group within the same sex (Scheffe's post hoc test). While sex differences are not noted on the graph, there are statistical differences between sex in all comparisons $(p<0.05$, independent t-test) except 70 $\leq$ of SBP, $70 \leq$ of DBP, and 50-59, 60-69, and $70 \leq$ of PP.

대상자는 전체의 $54.7 \%(2,809$ 명 중 1,536 명; 나이 보정 후 $50 \%)$ 여자는 $40.7 \%(3,761$ 명 중 1,529 명; 나이 보정 후 $35 \%)$ 이었다. 남자 높은정상혈압군 대상자는 전체의 $34.2 \%(2,809$ 명 중 962 명; 나이 보정 후 $33.0 \%)$ 여자는 $26.6 \%(3,761$ 명 중 999 명; 나이 보정 후 $23.6 \%$ )이었다. 높은정상혈압군과 고혈압군을 합한 경 우 각 연령대에서 남자는 $55,76,87,95,100 \%$ 가 여자는 17 , $40,64,84,93 \%$ 가 최소한 고혈압 위험군 이상에 속하였다. PP

Table 1. Height and weight of the population by the age group

\begin{tabular}{lcccc}
\hline \multirow{2}{*}{ Age group } & \multicolumn{2}{c}{ Man } & \multicolumn{2}{c}{ Woman } \\
\cline { 2 - 5 } & Height $(\mathrm{cm})(\mathrm{n})$ & Weight $(\mathrm{kg})$ & $160.2 \pm 5.3(318)$ & $60.7 \pm 10.9$ \\
$30-39$ & $172.2 \pm 6.1(268)$ & $74.0 \pm 11.9$ & $157.8 \pm 5.0(582)$ & $59.1 \pm 9.1$ \\
$40-49$ & $169.7 \pm 6.1(341)$ & $71.4 \pm 10.6$ & $155.3 \pm 5.3(1,068)$ & $59.4 \pm 8.5$ \\
$50-59$ & $167.4 \pm 5.6(566)$ & $68.6 \pm 10.2$ & $153.6 \pm 5.0(1,217)$ & $58.7 \pm 7.7$ \\
$60-69$ & $165.2 \pm 5.7(846)$ & $65.9 \pm 9.5$ & $151.5 \pm 5.0(576)$ & $56.6 \pm 7.5$ \\
$70 \leq$ & $164.4 \pm 5.8(788)$ & $64.7 \pm 8.7$ & & \\
\hline
\end{tabular}


Table 2. Description of population of hypertension and high-normal blood pressure

\begin{tabular}{|c|c|c|c|c|c|c|c|c|c|c|c|c|}
\hline & \multicolumn{6}{|c|}{ Man } & \multicolumn{6}{|c|}{ Woman } \\
\hline & \multicolumn{12}{|c|}{ Hypertensive } \\
\hline & $30-39$ & $40-49$ & $50-59$ & $60-69$ & $70 \leq$ & $\begin{array}{c}p \\
\text { (ANOVA) }\end{array}$ & $30-39$ & $40-49$ & $50-59$ & $60-69$ & $70 \leq$ & $\begin{array}{c}p \\
\text { (ANOVA) }\end{array}$ \\
\hline cases $(n)$ & 70 & 163 & 287 & 512 & 504 & --- & 20 & 119 & 386 & 630 & 374 & --- \\
\hline Age (yr) & $35.1 \pm 2.8$ & $44.9 \pm 3.0$ & $54.9 \pm 2.9$ & $65.1 \pm 2.8$ & $74.6 \pm 4.3$ & $<0.000^{*}$ & $34.6 \pm 2.9$ & $45.4 \pm 2.8$ & $55.3 \pm 2.8$ & $64.9 \pm 2.7$ & $74.0 \pm 3.9$ & $<0.000^{*}$ \\
\hline Height $(\mathrm{cm})$ & $173.7 \pm 6.0$ & $169.3 \pm 5.7$ & $167.2 \pm 5.4$ & $164.8 \pm 5.7$ & $164.4 \pm 5.9$ & $<0.000^{*}$ & $158.7 \pm 6.2$ & $157.7 \pm 5.7$ & $155.2 \pm 5.0$ & $153.5 \pm 5.0$ & $151.5 \pm 5.0$ & $<0.000^{*}$ \\
\hline Weight $(\mathrm{kg})$ & $80.8 \pm 13.9$ & $73.3 \pm 9.9$ & $69.8 \pm 10.6$ & $67.1 \pm 9.7$ & $65.4 \pm 9.0$ & $<0.000^{*}$ & $63.4 \pm 12.9$ & $63.3 \pm 10.9$ & $61.4 \pm 9.1$ & $59.9 \pm 7.8$ & $57.7 \pm 7.4$ & $<0.000^{*}$ \\
\hline $\begin{array}{l}\text { Body mass index } \\
\left(\mathrm{kg} / \mathrm{m}^{2}\right)\end{array}$ & $26.7 \pm 3.8$ & $25.6 \pm 3.0$ & $24.9 \pm 3.3$ & $24.7 \pm 3.1$ & $24.1 \pm 2.8$ & $<0.000^{*}$ & $25.1 \pm 4.4$ & $25.5 \pm 4.2$ & $25.5 \pm 3.6$ & $25.4 \pm 3.1$ & $25.1 \pm 3.1$ & $=0.554$ \\
\hline $\begin{array}{l}\text { Systolic blood } \\
\text { pressure }(\mathrm{mmHg})\end{array}$ & $146.4 \pm 1.0$ & $142.3 \pm 14.1$ & $141.6 \pm 15.5$ & $5143.6 \pm 17.8$ & $3144.3 \pm 16.9$ & $=0.089$ & $144.0 \pm 9.4$ & $143.5 \pm 14.1$ & $139.7 \pm 15.1$ & $140.1 \pm 16.5$ & $144.2 \pm 15.5$ & $5<0.000^{*}$ \\
\hline $\begin{array}{l}\text { Diastolic blood } \\
\text { pressure }(\mathrm{mmHg})\end{array}$ & $91.8 \pm 8.3$ & $93.6 \pm 10.2$ & $91.4 \pm 10.2$ & $88.2 \pm 12.0$ & $83.6 \pm 11.1$ & $<0.000^{*}$ & $96.2 \pm 11.6$ & $93.1 \pm 9.6$ & $87.8 \pm 10.6$ & $84.3 \pm 10.5$ & $82.8 \pm 9.5$ & $<0.000^{*}$ \\
\hline $\begin{array}{l}\text { Pulse pressure } \\
(\mathrm{mmHg})\end{array}$ & $54.6 \pm 10.3$ & $48.7 \pm 11.4$ & $50.2 \pm 11.4$ & $55.4 \pm 12.6$ & $60.7 \pm 13.7$ & $<0.000^{*}$ & $47.8 \pm 9.5$ & $50.4 \pm 11.5$ & $52.0 \pm 12.0$ & $55.8 \pm 12.0$ & $61.4 \pm 12.5$ & $<0.000^{*}$ \\
\hline $\begin{array}{l}\text { Total cholesterol } \\
(\mathrm{mg} / \mathrm{dl})\end{array}$ & $208 \pm 43$ & $198 \pm 41$ & $191 \pm 41$ & $190 \pm 41$ & $181 \pm 39$ & $<0.000^{*}$ & $183 \pm 38$ & $195 \pm 33$ & $199 \pm 43.8$ & $201 \pm 43.3$ & $205 \pm 45$ & $=0.054$ \\
\hline \multirow[t]{2}{*}{$\begin{array}{l}\text { HDL cholesterol } \\
(\mathrm{mg} / \mathrm{dl})\end{array}$} & $49.9 \pm 14.2$ & $45.8 \pm 13.9$ & $47.3 \pm 16.0$ & $47.6 \pm 15.3$ & $46.0 \pm 14.6$ & $=0.184$ & $55.6 \pm 11.5$ & $54.0 \pm 13.7$ & $52.7 \pm 14.8$ & $50.9 \pm 13.6$ & $50.6 \pm 14.8$ & $=0.037^{*}$ \\
\hline & \multicolumn{12}{|c|}{ High-normal blood pressure } \\
\hline cases (n) & 78 & 96 & 208 & 294 & 286 & --- & 33 & 113 & 300 & 394 & 159 & --- \\
\hline Age (yr) & $35.1 \pm 2.8$ & $44.8 \pm 3.0$ & $54.5 \pm 2.9$ & $65.2 \pm 2.8$ & $73.9 \pm 3.8$ & $<0.000^{*}$ & $34.6 \pm 3.0$ & $45.2 \pm 2.9$ & $55.1 \pm 2.8$ & $64.6 \pm 2.7$ & $73.8 \pm 3.7$ & $<0.000^{*}$ \\
\hline Height $(\mathrm{cm})$ & $173.1 \pm 5.7$ & $169.7 \pm 5.9$ & $168.0 \pm 5.5$ & $165.6 \pm 5.9$ & $164.1 \pm 5.7$ & $<0.000^{*}$ & $159.7 \pm 5.2$ & $158.1 \pm 5.3$ & $155.1 \pm 5.3$ & $153.8 \pm 5.0$ & $152.3 \pm 5.2$ & $<0.000^{*}$ \\
\hline Weight $(\mathrm{kg})$ & $76.6 \pm 11.1$ & $71.3 \pm 8.8$ & $70.0 \pm 9.7$ & $66.3 \pm 9.9$ & $64.6 \pm 8.5$ & $<0.000^{*}$ & $64.9 \pm 9.9$ & $62.0 \pm 9.9$ & $60.7 \pm 8.7$ & $59.8 \pm 8.1$ & $58.2 \pm 7.8$ & $<0.000^{*}$ \\
\hline $\begin{array}{l}\text { Body mass index } \\
\left(\mathrm{kg} / \mathrm{m}^{2}\right)\end{array}$ & $25.5 \pm 3.1$ & $24.7 \pm 2.5$ & $24.8 \pm 2.9$ & $24.2 \pm 3.1$ & $24.0 \pm 2.6$ & $<0.000^{*}$ & $25.5 \pm 4.4$ & $24.8 \pm 3.8$ & $25.2 \pm 3.3$ & $25.3 \pm 3.1$ & $25.1 \pm 3.1$ & $=0.677$ \\
\hline $\begin{array}{l}\text { Systolic blood } \\
\text { pressure }(\mathrm{mmHg})\end{array}$ & $135.9 \pm 8.9$ & $133.1 \pm 7.4$ & $134.0 \pm 7.0$ & $135.9 \pm 8.7$ & $137.7 \pm 8.7$ & $<0.000^{*}$ & $131.9 \pm 6.9$ & $133.5 \pm 6.9$ & $134.7 \pm 7.5$ & $136.7 \pm 8.0$ & $138.7 \pm 9.9$ & $<0.000^{*}$ \\
\hline $\begin{array}{l}\text { Diastolic blood } \\
\text { pressure }(\mathrm{mmHg})\end{array}$ & $84.4 \pm 6.1$ & $88.2 \pm 5.7$ & $86.6 \pm 6.2$ & $84.3 \pm 6.1$ & $81.9 \pm 7.5$ & $<0.000^{*}$ & $84.0 \pm 7.0$ & $86.1 \pm 6.3$ & $84.7 \pm 6.7$ & $82.8 \pm 7.0$ & $80.2 \pm 7.0$ & $<0.000^{*}$ \\
\hline $\begin{array}{l}\text { Pulse pressure } \\
(\mathrm{mmHg})\end{array}$ & $51.5 \pm 10.0$ & $45.0 \pm 8.8$ & $47.4 \pm 9.0$ & $51.6 \pm 9.6$ & $55.9 \pm 9.4$ & $<0.000^{*}$ & $47.9 \pm 9.9$ & $47.4 \pm 9.0$ & $50.1 \pm 9.7$ & $53.9 \pm 9.2$ & $58.5 \pm 9.0$ & $<0.000^{*}$ \\
\hline $\begin{array}{l}\text { Total cholesterol } \\
(\mathrm{mg} / \mathrm{dl})\end{array}$ & $199 \pm 39$ & $202 \pm 42$ & $192 \pm 40$ & $191 \pm 40$ & $183 \pm 37.2$ & $<0.000^{*}$ & $186 \pm 42$ & $190 \pm 38$ & $201 \pm 43$ & $205 \pm 41$ & $204 \pm 41.2$ & $<0.003^{*}$ \\
\hline $\begin{array}{l}\text { HDL cholesterol } \\
(\mathrm{mg} / \mathrm{dl})\end{array}$ & $49.1 \pm 13.5$ & $46.8 \pm 14.3$ & $48.5 \pm 16.4$ & $48.7 \pm 16.0$ & $46.2 \pm 14.1$ & $=0.273$ & $53.0 \pm 12.7$ & $55.4 \pm 14.4$ & $53.2 \pm 14.9$ & $51.4 \pm 13.4$ & $51.8 \pm 16.0$ & $=0.115$ \\
\hline
\end{tabular}

위험군은 50 대까지 $7 \%$ 이내의 수준에서 머물다가, 60 대에 들 어서면서 급격하게 증가하였다.

고혈압군의 경우 남자가 여자에 비해 모든 연령대에서 더 높은 경향을 보였으며 70세 이상의 연령대에서 유사한 비율을 (남 $63.9 \%$ vs. 여 64.9\%) 보였다. 연령대를 10세에서 5세로 나 누어 추가적 분석을 진행한 결과 65-69세에서는 남녀 각각 $60.0 \%$ 와 $63.4 \%$ 였으며, $70-74$ 세에서는 $62.5 \%$ 와 $63.4 \%$ 를 보였 다. 그러나 75 세 이상에서는 각각 $80.3 \%$ 와 $84.3 \%$ 를 보였다. 60세 초반을 전후하여 고혈압 발병률이 여자에게서 더 높게 나타나기 시작하였다. 높은정상혈압 발생률은 모든 연령대에 서 남자가 여자에 비해 높게 나타났다.

\section{고 찰}

본 연구는 우리나라의 한 지역사회 인구를 대상으로 이들의 연령에 따른 혈압의 변화추이를 파악하고 성별에 따라 다르게 나타날 것인가를 평가하는데 우선적인 목적을 두었다. 이미 알려진 바와 같이 혈압은 연령 증가와 함께 증가한다. 연령에 따른 혈압의 평가는 혈압이 수축기와 이완기로 측정되기에, 두 변인에 대한 평가가 따로 진행되어야 한다. 연구에 의하면 $\mathrm{SBP}$ 는 연령과 함께 지속적으로 증가한다[4]. 그렇지만 성별에 따른 증가추이는 다르다[5]. 남자는 20세 이후 완만하고 지속 적으로 증가하는 반면 여자는 남자들에 비해 20세부터 낮은 

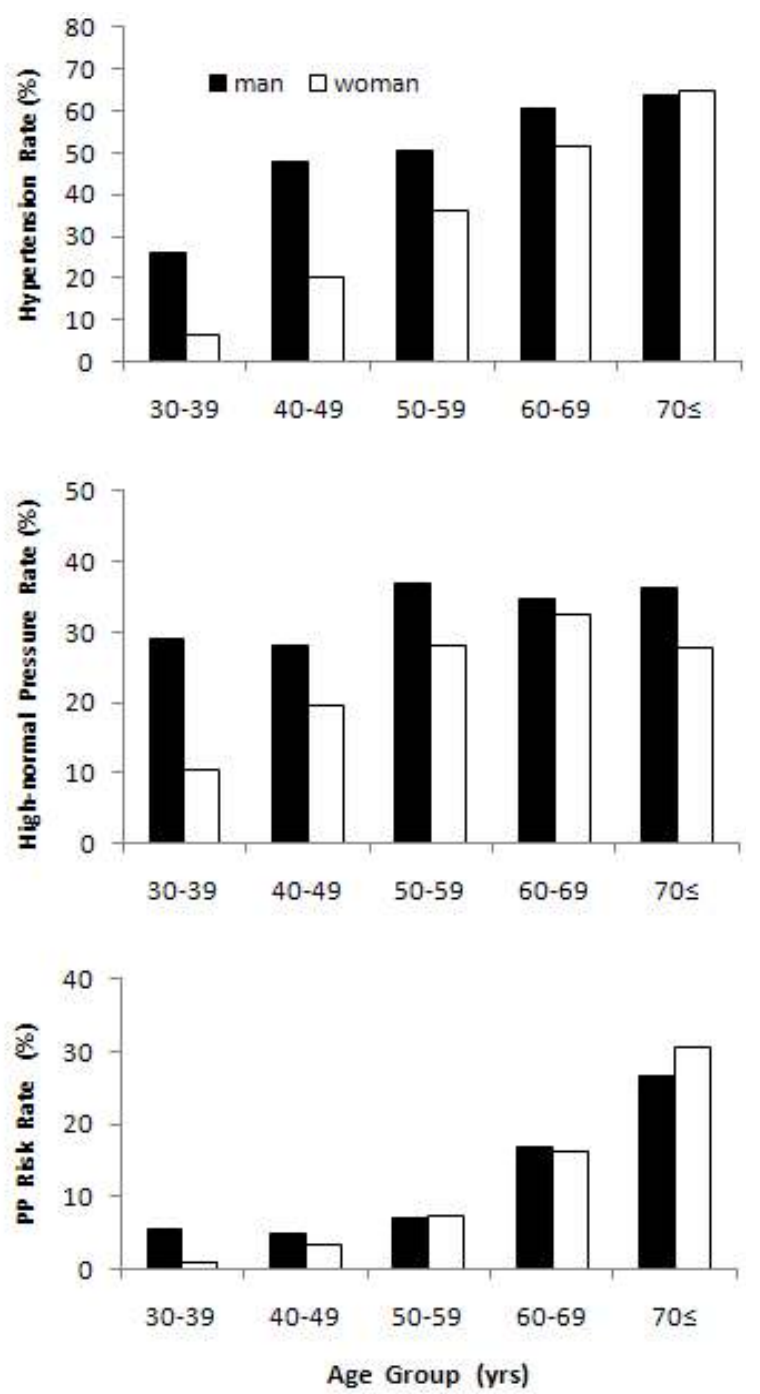

Fig. 2. Hypertension, high-normal blood pressure, and pulse pressure risk criteria rate in man and woman by the age group.

혈압을 유지하지만 그 증가폭이 크게 나타나고 결국 노년기에 서는 남자와 여자의 혈압유병률이 역전된다. 이 연구에서는 서양인들에게서 나타나는 연령에 따른 $\mathrm{SBP}$ 의 증가양상 그리 고 남녀 간의 발전양상이 유사하게 관찰되었다.

서양인의 경우 $\mathrm{DBP}$ 는 20세부터 60세까지 완만한 증가추세 를 보이다가 이후 감소하게 된다[5]. 그리고 이러한 추세는 성 별, 인종과 무관하게 나타나며, 혈압의 높고 낮음과 상관없이 모든 영역에서의 혈압 소유자에게 동등하게 나타난다[4]. 본 연구에서는 서양인들에서 나타난 $\mathrm{DBP}$ 의 변화양상과는 다른 변화추세와 절대적 수치가 관찰되었다. 남자의 경우 30 대 평 균 $79 \mathrm{mmHg}$ 에서 40 대에 $85 \mathrm{mmHg}$ 를 보였다가 이후 완만하 게 감소하여 70 세 이상 연령대에서는 $80 \mathrm{mmHg}$ 를 보였다. 서 양인들을 대상으로 하는 이전의 연구들이 50-60대에서 DBP의 최고점을 보고한 것 $[4,5]$ 에 비교하면 본 연구에서 $\mathrm{DBP}$ 의 최고
점이 40 대에서 형성된 것과 평균 $\mathrm{DBP}$ 의 수준이 40 세 이후에 서 지속적으로 $80 \mathrm{mmHg}$ 를 유지하였다는 것은 서양인과 본 연구의 대상이 서로 다른 경향을 보인다는 것을 의미한다. 3차 National Health And Nutrition Examination Survey (NHANES)에 의하면 남자의 경우 모든 인종에서 $\mathrm{DBP}$ 가 50대 에 최고점을 이루었으며 이때 약 $80 \mathrm{mmHg}$ 를 약간 상회하는 추세를 보였다[5]. 본 연구의 연령에 따른 남자의 DBP 변화추 세와 수치가 이미 제시된 서양인이 그것과 비교해 다르게 나 타난 것에 대한 원인은 아직 명확하지 않다. 한국남자의 연령 별 $\mathrm{DBP}$ 변화추이에 대한 추가적인 연구가 필요해 보인다. 이 에 반해 본 연구에서 관찰된 여자의 경우는 서양인들을 대상 으로 보고된 연구들의 결과와 유사하게 나타났다[5]. 즉 이 연 구의 여자 대상자들은 약 60 세까지 지속적으로 증가세를 보였 으며 이후 완만한 감소세를 보였다. 또한 그 범위도 이전의 보고와 마찬가지로 평균 약 $72-79 \mathrm{mmHg}$ 의 범위를 유지하였 다. 최소한 여자의 경우 서양인과 본 연구의 대상자가 같은 연령에 따른 추세에 있어 유사함을 보였다.

$\mathrm{SBP}$ 와 $\mathrm{DBP}$ 의 차이로 환산되는 $\mathrm{PP}$ 는 결과적으로 전자의 두 혈압요인과 같이 연령에 따라 증가하게 된다[10,14]. 특히 $\mathrm{DBP}$ 가 $\mathrm{SBP}$ 와 동반하여 증가하다가 그 증가 양상이 감소 양상 으로 변하는 시점부터 그 증가 폭은 커지게 된다. 혈관압력은 노화와 함께 유전적, 환경적 요인들이 복합적으로 작용하여 동맥벽의 구조와 기능이 변화됨으로써 혈관이 탄력성 (elasticity)을 잃게 되어 변화된다[24]. 혈관탄성이 건강한 상 태를 유지하지 못하는 경우 $\mathrm{SBP}$ 가 증가하고 반대로 $\mathrm{DBP}$ 가 감소하여 결과적으로 $\mathrm{PP}$ 가 증가하게 되는 것이다. 비록 $\mathrm{PP}$ 가 뇌졸중과 관상심장질환을 예견하는데 $\mathrm{SBP}$ 와 $\mathrm{DBP}$ 에 비해 정 확성이 떨어진다는 보고가 있지만[19], $\mathrm{PP}$ 의 증가는 심근경색 (myocardial infarction) 유발의 위험성을 높이며[9], 모든 혈압 군에서 심혈관계에 의한 사망률을 높이는 것으로 알려지고 있다[2].

생리학적으로 $\mathrm{PP}$ 는 $\mathrm{MAP}$ 의 영역에서 혈관벽에 반복적이며 파동적인 혈액의 압력으로 설명되지만 $\mathrm{MAP}$ 와는 다른 조절 기전을 가진다. MAP 는 심장사이클(cardiac cycle) 동안 심박 출량에 의한 대동맥과 주요동맥에 가해지는 평균적인 압력이 며[24], 주요 동맥혈관 대부분의 영역에서 거의 일정하게 유지 된다. 이와는 달리 $\mathrm{PP}$ 는 $\mathrm{SBP}$ 와 $\mathrm{DBP}$ 에 의해 결정 된다. 특히 큰동맥에서 말초동맥으로 이동할수록 $\mathrm{SBP}$ 는 증가하고 $\mathrm{DBP}$ 는 소폭 감소하여 결국 말초혈관에서의 $\mathrm{PP}$ 는 현저하게 증가하 는 결과를 보인다. 만약 일정한 일회박출량과 심실박출속도가 유지된다고 가정한다면 $\mathrm{PP}$ 는 혈액이 지나는 도관, 즉 혈관의 상태에 따라 결정지어진다. 여기서 혈관의 상태란 혈관벽의 점탄성질을 의미하며, 노화와 동반되는 혈관성질의 변형은 $\mathrm{SBP}$ 의 증가와 $\mathrm{DBP}$ 의 감소를 유발하여 결국 $\mathrm{PP}$ 를 증가시킨다 [15].

이 연구에서의 재미있는 관찰은 50 세 이후 남녀의 $\mathrm{PP}$ 에 차 
이가 존재하지 않으면서 급격히 증가했다는 것이다. 게다가 50 세 이후 SBP는 남자에게서 완만한 증가, 여자에게서 급격한 증가가 나타나는 반면, $\mathrm{DBP}$ 는 남자에게서 급격한 감소, 여자 에게서 일정수준 유지가 나타났다는 점이다. $\mathrm{SBP}$ 가 변하지 않으면서 $\mathrm{PP}$ 가 증가하는 것은 $\mathrm{DBP}$ 가 감소하는 이유이며, 이 는 큰동맥이 굳음(stiffness)으로써 발생하는 결과이다[3]. 다른 현상으로, $\mathrm{SBP}$ 가 증가하면서 $\mathrm{PP}$ 가 변하지 않는 경우는 $\mathrm{DBP}$ 가 $\mathrm{SBP}$ 와 동반으로 증가하는 것을 의미하며 이는 말초혈관저항 이 증가하기 때문이다[3]. 결과적으로 이 연구에서 50 세 이후 의 남자는 큰동맥들의 굳음현상이 보다 가속화되는 것이 말초 혈관 저항의 증가보다 고혈압 증가현상에 중요한 요인으로 작용한 것으로 해석할 수 있다. 이에 반해 같은 연령대의 여자 는 고령으로 접어들면서 다양한 요인에 의해 $\mathrm{PP}$ 가 결정되는 것으로 보인다. $\mathrm{DBP}$ 의 변화 없이 $\mathrm{SBP}$ 가 증가하는 현상은 아마 도 1회심박출량 또는 심실박출율(ventricular ejection rate)가 증가하기 때문인 것으로 보이며, 이는 심장기능에 상당한 부 담으로 작용한다.

$\mathrm{PP}$ 의 증가가 어떠한 원인에 근거하든 분명한 관찰은 50 세 이후 남녀 모두에서 $\mathrm{PP}$ 가 급격하게 증가하고 또한 $\mathrm{PP}$ 위험군 비율이 60세 이후에 급격하게 증가하는 것은 공중보건의 측면 에서 주목할 사실이다. $\mathrm{PP}$ 의 급격한 변화는 심혈관계에 의한 사망률 특히 관상동맥에 의한 사망률을 증가시킨다[28]. SBP 의 증가는 수축기말스트레스(end-systolic stress)가 불균형적 으로 증가하는 원인으로 작용하여, 심근비대(cardiac hypertrophy), 심실산소섭취량(ventricular oxygen uptake), 좌심실 비대(left ventricular hypertrophy)를 유도한다[23].

이 연구에서 지역사회 인구 대상자들의 고혈압 유병률은 남녀 각각 $49.8 \%$ 와 $35.9 \%$ 로 나타났다. 이는 국민건강통계에서 제시한 2009년 만 30세 이상 남자와 여자보다 각각 $14.7 \%$ 와 $7 \%$ 가 높은 수준이다. 대단위 인구를 대상으로 한 조사와 이번 연구의 결과에 차이가 존재하는 것은 아마도 보건소의 건강증 진사업이라는 특징 때문인 것으로 보인다. 연구의 목적에 맞 추어 수입과 교육수준을 고려하지 않았으며 단지 절대적 기준 에 의해 고혈압인구를 구분하였기 때문인 것으로도 풀이된다.

이 연구에서 주목할 점은 최소한 높은정상혈압 이상을 소유 하고 있는 대상자가 남자의 경우 40 대에서 4 명 중 3 명(약 $75 \%$ ) 이, 여자의 경우에서도 50 대부터 10 명 중 6 명 $($ 약 $60 \%$ )이 해당 된다는 것이다. 고혈압의 심혈관질환 사망률과의 높은 상관관 계에도 불구하고 높은정상혈압군에 대한 우려와 관리에 대한 필요성은 지속적으로 제기되어왔다. 최근의 JNC-7 보고서에 의하면 높은정상의 혈압을 가진 사람들과 같은 미래의 심혈관 질환자와 고혈압환자에 대한 적극적인 개입이 필요함을 표명 하고 있다[7]. 개입의 시기와 개입 대상자에 대한 이견은 존재 할지라도 결국 높은정상혈압의 소유자는 고혈압환자로 진전 될 것은 거의 분명한 사실이기 때문이다[29], 국민건강보험공 단의 자료를 분석한 결과에서는 전고혈압(pre-hypertension)
단계의 젊은이와 여성이 미래에 고혈압이 발병할 확률이 높음 을 지적하고 있다[16].

인종에 따른 고혈압 발병률에 대한 연구는 일관적인 결과를 보이고 있지 않다. 45-84세의 성인 3146명을 대상으로 4.8 년간 추적 조사한 연구에서는 45-74세의 흑인들이 백인들에 비해 고혈압 발병률이 높은 것으로 나타났으나 이후의 연령에서는 차이가 없는 것으로 나타났다. 그리고 남미인들이 백인들에 비해 높게 나타났으나 중국인들은 백인들에 비해 고혈압 발병 률에서 아무런 차이를 보이지 않았다[6]. 또 다른 연구에서도 흑인의 고혈압 발병률 $(60 \%)$ 이 백인( $38 \%)$ 보다 높았으며, 남미 인(42\%)과 중국인(39\%)은 백인과 유의한 차이를 보이지 않았 다[19].

종합적으로 남자와 여자 모두에서 $\mathrm{SBP}$ 는 연령 증가에 따라 지속적으로 증가하였다. 여자가 남자에 비해 거의 일생동안 낮은 수준을 유지하였으나 빠른 증가추세를 보여 60세 중반에 서부터는 그 수치가 역전되는 것으로 나타났다. $\mathrm{DBP}$ 의 경우 여자가 남자에 비해 낮았으며, 남자는 40 대를 정점으로 하강 하였으며, 여자는 4-50대를 거쳐 거의 일정하게 유지하였다. 남녀의 $\mathrm{PP}$ 는 50 대 이후에 가파르게 동반 증가하였다. 남자는 50 대 이후 큰동맥들의 굳음현상이 고혈압 증가의 주된 원인으 로 보이며, 여자는 다양한 요인에 기인하는 것으로 보인다. $\mathrm{PP}$ 의 증가는 심장에 부담을 줄 것이며, 특히 50대 이후 남녀 모두에서 가파른 위험가중이 관찰된다. 이 연구에서 고혈압 발병률은 이전에 보고된 것들에 비해 높게 나타났다. 높은정 상혈압을 고혈압 위험군에 포함시킨다면 고혈압 관리를 위한 대상자의 범위는 상당히 확장될 것으로 보인다.

\section{감사의 글}

본 연구는 2011년도 국민대학교 교내연구비를 지원받아 수 행된 연구임.

\section{References}

1. Anderson, K. M., P. W. F. Wilson, P. M. Odell, and W. B. Kannel. 1991. An updated coronary risk profile. A statement for health professionals. Circulation 83, 356-362.

2. Benetos, A., A. Rudnichi, M. Safar, and L. Guize. 1998. Pulse pressure and cardiovascular mortality in normotensive and hypertensive subjects. Hypertension 32, 560-564.

3. Berne, R. M. and M. N. Levy. 1992. Cardiovascular Physiology. pp. 113-144, CV Mosby Company. St Louis, Missouri.

4. Black, H. R. 2004. The paradigm has shifted to systolic blood pressure. J. Hum Hypertension 18, S3-S7.

5. Burt, V. L., P. Whelton, E. J. Roccella, C. Brown, J. A. Cutler, M. Higgins, M. J. Horan, and D. Labarthe. 1995. Prevalence of hypertension in the US adult population. Results from 
the Third National Health and Nutrition Examination Survey, 1988-1991. Hypertension 25, 305-313.

6. Carson, A. P., G. Howard, G. L. Burke, S. Shea, E. B. Levitan, and P. Muntner. 2011. Ethnic differences in hypertension incidence among middle-aged and older adults: The multi-ethnic study of atherosclerosis. Hypertension 57, 1101-1107.

7. Chobanian, A. V., G. L. Bakris, H. R. Black, W. C. Cushman, L. A. Green, J. L. Izzo Jr., D. W. Jones, B. J. Materson, S. Oparil, J. T. Wright Jr., and E. J. Roccella. 2003. The Seventh Report of the Joint National Committee on Prevention, Detection, Evaluation, and Treatment of High Blood Pressure: the JNC 7 report. JAMA 289, 2560-2572.

8. Conen, D., P. M. Ridker, J. E. Buring, and R. J. Glynn. 2007. Risk of cardiovascular events among women with high normal blood pressure or blood pressure progression: prospective cohort study. Br. Med J. 335, 432-440.

9. Fang, J., S. Madhavan, H. Cohen, and M. H. Alderman. 1995. Measures of blood pressure and myocardial infarction in treated hypertensive patients. J. Hypertens 13, 413-419.

10. Franklin, S. S., W. G. Gustin, N. D. Wong, M. G. Larson, M. A. Weber, W. B. Kannel, and D. Levy. 1997. Hemodynamic patterns of age-related changes in blood pressure: the Framingham Heart Study. Circulation 96, 308-315.

11. Franklin, S. S., S. A. Khan, N. D. Wong, M. G. Larson, and D. Levy. 1999. Is pulse pressure useful in predicting risk for coronary heart Disease? The Framingham heart study. Circulation 100, 354-360.

12. Gasowski, J. R. H. Fagard, J. A. Staessen, T. Grodzicki, S. Pocock, F. Boutitie, F. Gueyffier, and J. P. Boissel. 2002. Pulsatile blood pressure component as predictor of mortality in hypertension: a meta-analysis of clinical trial control groups. J. Hypertens 20, 145-151.

13. Kannel, W. B. 1996. Blood pressure as a cardiovascular risk factor: prevention and treatment. JAMA 275, 1571-1576.

14. Kannel, W. B., P. A. Wolf, D. L. McGee, T. R. Dawber, P. McNamara, and W. P. Castelli. 1981. Systolic blood pressure, arterial rigidity, and risk of stroke. JAMA 245, 1225-1229.

15. Kelly, R., R. Tunin, and D. Kass. 1992. Effect of reduced aortic compliance on left ventricular contractile function and energetics in vivo. Circ. Res. 71, 490-502.

16. Kim, S. J., J. Lee, C. M. Nam, S. H. Jee, I. S. Park, K. J. Lee, and S. Y. Lee. 2010. Progression rate from new-onset pre-hypertension to hypertension in Korean adults. Circ. J. 75, 135-140.

17. Kobalava, A. D., Y. V. Kotovskaya, L. A. Babaeva, and V. S. Moiseev. 2006. Validation of TM-2655 oscillometric device for blood pressure measurement. Blood Press. Monit. 11, 87-90.

18. Korea National Health Statistics 2009, 2010. pp. 54, Ministry of Health and Welfare, Korea

19. Kramer, H., C. Han, W. Post, D. Goff, A. Diez-Roux, R. Cooper, S. Jinagouda, and S. Shea. 2004. Racial/ethnic differences in hypertension and hypertension treatment and control in the multi-ethnic study of atherosclerosis (MESA). Am J. Hypertens 17, 963-970.

20. Lewington, S., R. Clarke, N. Qizilbash, R. Peto, and R. Collins. 2002. Age-specific relevance of usual blood pressure to vascular mortality: a meta-analysis of individual data for one million adults in 61 prospective studies. Lancet 360, 1903-1913.

21. Madhavan, S., W. L. Ooi, H. Cohen, and M. H. Alderman. 1994. Relation of pulse pressure and blood pressure reduction to the incidence of myocardial infarction. Hypertension 23, 395-401.

22. Nichols, W. W., F. A. Nicolini, and C. J. Pepine. 1992. Determinants of isolated systolic hypertension in the elderly. J. Hypertens 10, S73-S77.

23. Pannier, B., P. Brunel, W. El Aroussy, P. Lacolley, and M. E. Safar. 1989. Pulse pressure and echocardiographic findings in essential hypertension. J. Hypertens 7, 127-129.

24. Safar, M. E. 1989. Pulse pressure in essential hypertension: clinical and therapeutical implications. J. Hypertens 7, 769-776.

25. Sagie, A., M. G. Larson, and D. Levy. 1993. The natural history of borderline isolated systolic hypertension. $N$. Engl. J. Med 329, 1912-1917.

26. Vasan, R. S., M. G. Larson, E. P. Leip, J. C. Evans, C. J. O'Donnell, W. B. Kannel, and D. Levy. 2001. Impact of high-normal blood pressure on the risk of cardiovascular disease. N. Engl. J. Med 345, 1291-1297.

27. Vasan, R. S., A. Beiser, S. Seshadri, M. G. Larson, W. B. Kannel, R. B. D'Agostino, and D. Levy. 2002. Residual lifetime risk for developing hypertension in middle-aged women and men: The Framingham Heart Study. JAMA 287, 1003-1010.

28. Watanabe, H., S. Ohtsuka, M. Kakihana, and Y. Sugishita. 1993. Coronary circulation in dogs with experimental decrease in aortic compliance. J. Am Coll. Cardiol. 21, 1497-1506.

29. Zhang, H., L. Thijs, T. Kuznetsova, R. H. Fagard, X. Li, and J. A. Staessen. 2006. Progression to hypertension in the non-hypertensive participants in the Flemish Study on Environment, Genes and Health Outcomes. J. Hypertens 24, 1719-1727. 


\section{초록 : 한국 성인의 연령에 따른 혈압변화 양상과 고혈압 유병률}

\section{이대택* $\cdot$ 이용수}

(국민대학교 체육대학 운동생리학실험실)

한국인의 연령에 따른 혈압변화와 고혈압 유병률 그리고 수축기(SBP)와 이완기(DBP)혈압 및 맥압(PP)의 변화 양상을 횡단적으로 평가하였다. 지역보건소 건강검진 및 건강증진프로그램을 통해 진료된 대상자 6,570명(남 $2,809$, 여 3,761$)$ 을 5 연령군 $(30,40,50,60$ 대 그리고 70 세 이상)으로 구분하여 비교 분석하였다. SBP는 지속적으로 증가하였으며, 남자가 여자에 비해 높게 유지되었다. 그러나 60대 중반에서 역전되었다. DBP는 남자 30대부터 증가하여 40대에서 최고점을 이르렀다가 하강하였다. 여자는 4-50대까지 증가하다가 일정한 수준을 유지하였다. 남녀 모두에서 $\mathrm{PP}$ 는 50대 이후 가파르게 증가하였다. 남자의 경우 특히 50대 이후의 연령과 관계한 혈압의 증가 는 큰동맥의 굳어짐 현상이 가장 큰 공헌을 하는 것으로 보이며, 여성의 경우는 큰동맥굳어짐, 일회심박출량 또는 심실박출율과 같은 다양한 원인에 기인하는 것으로 평가된다. PP의 증가는 심장에 부담을 주게 되며 특히 50대 이후 남녀 모두에서 가파른 위험성이 예견된다. 이 연구에서는 남녀 모두에서 고혈압 발병률이 이전의 연구들에 비해 높게 나타나고 있다. 높은정상혈압을 고혈압 위험군에 포함시킨다면 고혈압 관리를 위한 대상자의 범위는 상당히 확장될 것으로 보인다. 